Article

\title{
Temperature-Time Superposition Effect on Compressive Properties of AZ31B Magnesium Composite Foams
}

\author{
Xingchuan Xia ${ }^{1,2,+}$, Jing Wang ${ }^{1,+}{ }^{\text {, }}$ Yuanyi Peng ${ }^{1,+}$, Nannan Wang $^{1}$, Xin He ${ }^{1}$, Chuanrong Qiu ${ }^{1}$, \\ Jian Ding ${ }^{1, *}$ and Xueguang Chen ${ }^{1, *}$ \\ 1 School of Materials Science \& Engineering, Hebei University of Technology, Tianjin 300401, China; \\ xc_xia@hebut.edu.cn (X.X.); w1225377693@163.com (J.W.); 15773289910@163.com (Y.P.); \\ w13820962170@163.com (N.W.); jikemuku@163.com (X.H.); qiuchuanrongnk@126.com (C.Q.) \\ 2 State Key Lab of Hydraulic Engineering Simulation and Safety, School of Materials Science \& Engineering, \\ Tianjin University, Tianjin 300354, China \\ * Correspondence: djian0122@126.com (J.D.); cxg@hebut.edu.cn (X.C.); Tel.: +86-22-6020-4477 (J.D.); \\ +86-22-6020-2414 (X.C.) \\ + These authors contributed equally to this work.
}

Received: 22 May 2018; Accepted: 6 June 2018; Published: 8 June 2018

\begin{abstract}
Magnesium composite foams with 10 vol. \% of hollow ceramic microspheres (CMs) were prepared by modified melt foaming method. Specimens with homogeneous pore structures were subjected to various heating temperature $\left(150,250,320,400\right.$, and $500{ }^{\circ} \mathrm{C}$, respectively) and enduring times (1, 2, 4, 6, and $24 \mathrm{~h}$, respectively). Evolution of microstructure and mechanical properties of the samples, before and after the heating processes were examined by applying $\mathrm{X}$-ray diffraction technique (XRD), differential scanning calorimetry (DSC), scanning electron microscopy (SEM), and quasi-static uniaxial compression test. The results showed that as heating temperature and enduring time increasing, $\beta-\mathrm{Mg}_{17} \mathrm{Al}_{12}$ phases gradually dissolved, resulting in a solid-solution strengthening effect. Meanwhile, internal stress relaxation in the matrix leads to the decrease of yield strength and micro hardness of the specimens. When compared with the unheated foams, the treated specimens possessed lower micro-hardness, yield strength, and energy absorption capacity due to the dissolution of $\beta-\mathrm{Mg}_{17} \mathrm{Al}_{12}$ phases and the release of internal stress. However, higher strain hardening exponents for almost all of the treated composite foams were observed and the reasons were discussed. It is proposed that more factors should be taken into account when using heated composite foams in practical applications.
\end{abstract}

Keywords: magnesium composite foams; microstructure; compressive property; heating effect

\section{Introduction}

In the last few decades, metal matrix syntactic foams (MMSF) with inherent properties of low density, high specific strength, and unique energy absorption capacity have received great attention [1-3]. In recent years, $\mathrm{Al} / \mathrm{Mg}$ matrix syntactic foams are promising weight reduction materials, particularly attention for being used in automobile, aviation, and consumer products fields $[4,5]$. While, up to date, most of the investigations focused on aluminum or aluminum alloy matrices [6-8], only a few studies are available on Mg matrix syntactic foams, e.g., ZC63 magnesium-microballoon composite foams were fabricated by melt stir technique and the processing parameters on the distribution of fly ash microballoons were investigated. Meanwhile, the main interfacial phase between fly ash and ZC63 matrix was MgO, also eutectic and other intermatellic compounds, were found on the interface [6]. Besides, the compressive properties with different 
contents of fly ash microballoons were also studied [8]. The interaction behavior between AE44 magnesium alloy and $\mathrm{SiC}-\mathrm{Al}_{2} \mathrm{O}_{3}-\mathrm{SiO}_{2}$ ceramic foam was studied, and it was revealed that $\mathrm{SiO}_{2}$ was predominantly reduced by $\mathrm{Mg}$ during the contact of magnesium-rich melt with the ceramics. The main reaction product was $\mathrm{MgO}$ with $\mathrm{Si}$ element dissolving into the melt [9]. In our previous research, closed-cell AZ31 magnesium composite foams with different percentages of hollow ceramic microspheres (CMs) were successfully prepared by modified melt foaming method and the effects of CMs on the porosity, pore size, and quasi-static compressive behaviors were characterized [10]. It was found that compression fracture mode of the foams changed from brittleness to ductility if the proper percentage of CMs was added.

It is reported that the behavior of magnesium composite foams under various environmental conditions is not yet studied [6]. In addition, from the engineering application perspective, it is significant to consider whether the composite foams can be reused when the foams were subjected to different heating conditions and further studies are needed. Therefore, this work aims to investigate the influence of different heating temperatures and enduring times on the evolution of microstructure and compressive properties of AZ31 magnesium composite foams. The variations of micro-hardness, compressive characterization, and strain hardening exponent under different heating conditions were investigated and the reasons were discussed.

\section{Experimental Procedures}

\subsection{Specimens Fabrication}

AZ31B magnesium alloys with the compositions that are shown in Table 1 were used as base materials. Analytically pure grade $\mathrm{Ca}$ particles and $\mathrm{CaCO}_{3}$ powders were used as thickening agent and foaming agents, respectively. CMs with the composition and parameter shown in Table 2 were used as the compound material. A modified melt foaming method was applied and the detailed fabrication processes, as follows: (1) cutting magnesium ingot into sheets with of $10 \sim 15 \mathrm{~mm}$ by electro-discharging machine, (2) place the magnesium alloy sheets and CMs layer by layer in a mid steel crucible, (3) the layered composite materials with the steel crucible are heated together to a fixed temperature, (4) $0.2 \mathrm{wt}$. \% Ca was added into the melt accompanied by a mechanical stirrer with stirring speed of $500 \mathrm{r} / \mathrm{min}$ for $8 \mathrm{~min}$, (5) then $1.5 \mathrm{wt}$. $\% \mathrm{CaCO}_{3}$ powders were added with stirring speed of $1200 \mathrm{r} / \mathrm{min}$ for $40 \mathrm{~s}$, and (6) the melt was held for $2 \mathrm{~min}$ and then cooled in air. In this work, 10 vol. \% CMs were added into AZ31B magnesium alloys and the melting temperature was $680{ }^{\circ} \mathrm{C}$ $\mathrm{CO}_{2}$ and $\mathrm{SF}_{6}$ mixture gas was used to protect the melt from being ignited or oxidized during the whole procedure. Specimens that were used for microstructure observation and mechanical test were cut into cylindrical samples with diameter of $11 \mathrm{~mm}$ and height of $15 \mathrm{~mm}$ by electro-discharging machining.

Table 1. AZ31B chemical compositions (wt. \%).

\begin{tabular}{ccccccccc}
\hline $\mathbf{M g}$ & $\mathbf{A l}$ & $\mathbf{Z n}$ & $\mathbf{M n}$ & $\mathbf{F e}$ & $\mathbf{S i}$ & $\mathbf{C u}$ & $\mathbf{C a}$ & Total Imp. \\
\hline Balance & 3.1148 & 0.8109 & 0.3197 & 0.0002 & 0.0081 & 0.0003 & 0.0002 & 0.1 \\
\hline
\end{tabular}

Table 2. Composition and parameter of ceramic microspheres (CMs).

\begin{tabular}{ccccc}
\hline $\mathrm{Al}_{2} \mathbf{O}_{3}(\mathbf{w t} \%)$ & $\mathrm{SiO}_{\mathbf{2}}(\mathbf{w t} \%)$ & Stacking Desity $\left(\mathbf{g} / \mathrm{cm}^{\mathbf{3}}\right)$ & Size Range $(\boldsymbol{\mu m})$ & Wall Thickness $(\mu \mathrm{m})$ \\
\hline$\sim 10$ & $\sim 90$ & 0.42 & $40-150$ & $7.5 \pm 0.8$ \\
\hline
\end{tabular}

The density and porosity were determined by Equation (1) [11,12]:

$$
P_{r}=\left[V-\left(M / \rho_{s}\right)\right] / V \times 100 \%
$$


where $P_{r}$ is foam porosity, $\rho_{s}$ is matrix density, $M$ is foam weight $(\mathrm{g})$, and $V$ is foam volume $\left(\mathrm{mm}^{3}\right)$. Specimens with similar porosity of $67 \%$ (as shown in Table 3) were used in this work and the pore sizes were determined by mean intercept length technique.

Table 3. Thermal treatment parameters and physical properties of the foams.

\begin{tabular}{|c|c|c|c|c|}
\hline Temperature $\left({ }^{\circ} \mathrm{C}\right)$ & Time (h) & Porosity (\%) & Pore Size (mm) & Specimens Size $(\mathrm{mm})$ \\
\hline \multirow{5}{*}{150} & 1 & 67.40 & \multirow{5}{*}{$1 \sim 2$} & \multirow{5}{*}{$\Phi 10 \times 15$} \\
\hline & 2 & 67.30 & & \\
\hline & 4 & 67.20 & & \\
\hline & 6 & 66.70 & & \\
\hline & 24 & 67.22 & & \\
\hline \multirow{5}{*}{250} & 1 & 66.56 & \multirow{5}{*}{$1 \sim 2$} & \multirow{5}{*}{$\Phi 10 \times 15$} \\
\hline & 2 & 67.39 & & \\
\hline & 4 & 66.90 & & \\
\hline & 6 & 67.40 & & \\
\hline & 24 & 67.53 & & \\
\hline \multirow{5}{*}{320} & 1 & 67.41 & \multirow{5}{*}{$1 \sim 2$} & \multirow{5}{*}{$\Phi 10 \times 15$} \\
\hline & 2 & 67.50 & & \\
\hline & 4 & 67.25 & & \\
\hline & 6 & 67.31 & & \\
\hline & 24 & 67.19 & & \\
\hline \multirow{5}{*}{400} & 1 & 67.30 & \multirow{5}{*}{$1 \sim 2$} & \multirow{5}{*}{$\Phi 10 \times 15$} \\
\hline & 2 & 67.27 & & \\
\hline & 4 & 66.90 & & \\
\hline & 6 & 67.07 & & \\
\hline & 24 & 67.10 & & \\
\hline \multirow{5}{*}{500} & 1 & 67.20 & \multirow{5}{*}{$1 \sim 2$} & \multirow{5}{*}{$\Phi 10 \times 15$} \\
\hline & 2 & 67.40 & & \\
\hline & 4 & 67.28 & & \\
\hline & 6 & 66.90 & & \\
\hline & 24 & 67.20 & & \\
\hline As-received & - & 67.36 & $1 \sim 2$ & $\Phi 10 \times 15$ \\
\hline
\end{tabular}

\subsection{Thermal Treatment}

Different heating temperatures of $150{ }^{\circ} \mathrm{C}, 250{ }^{\circ} \mathrm{C}, 320^{\circ} \mathrm{C}, 400{ }^{\circ} \mathrm{C}, 500{ }^{\circ} \mathrm{C}$ and enduring times of $1 \mathrm{~h}, 2 \mathrm{~h}, 4 \mathrm{~h}, 6 \mathrm{~h}, 24 \mathrm{~h}$ were selected for thermal treatment. Graphite powders were used to cover all of the specimens to avoid being ignited and oxidized. Electrical resistance furnace was applied for all of the thermal treatments with detailed process parameters shown in Table 3. It should be noted that all of the specimens were quenched in room temperature water immediately when they were taken out of the furnace. For each parameter, three samples were treated.

\subsection{Microstructure Observation}

Samples that were used for microstructure observation were ground through successive grades, and finally to 3000 grit emery paper, then polished by using $0.5 \mu \mathrm{m}$ polishing paste, and finally etched with 4 vol. \% nitric acid alcohol. Olymups-BX41M optical microscope (OM, Olymups Corporation, Tokyo, Japan) and Zeiss MA15 scanning electron microscope (SEM, Carl Zeiss, Oberkochen, Germany) equipped with energy-dispersive spectra (EDS) were used for microstructure and pores morphology observation. SmartLab X-ray diffraction (XRD, Rigaku Corporation, Tokyo, Japan) using copper K $\alpha$ radiation was applied for phase compositions calibration. SDT Q-600 differential scanning calorimeter (DSC, TA Instruments-water LLC, Newcastle, DE, USA) with heating rate of $10^{\circ} \mathrm{C} / \mathrm{min}$ was used to measure the phase change process. 


\subsection{Mechanical Property Test}

The compressive properties were examined using SUNS Electron Universal Material Testing Machine (Shenzhen SUNS Technology Stock Co., Ltd., Shenzhen, China) with a maximum load of $100 \mathrm{kN}$ and a displacement speed of $1.5 \mathrm{~mm} / \mathrm{min}$ (with the corresponding initial strain rate of $0.002 \mathrm{~s}^{-1}$ ) at room temperature. All of the results were recorded in a personal computer. For each parameter, three samples were compressed to ensure the reproducibility and the average data were used. The micro-hardness (HMV) was tested through a HMV-2Tmicroscopic hardness tester (Shimadzu Co., Kyoto, Japan) with the load of $10 \mathrm{~g}$ and loading time of $10 \mathrm{~s}$, at least eight detections were applied and the average data were used in this work.

\section{Results}

\subsection{Pore Structure and Morphology}

Figure 1a shows the macrograph of the composite foam with 10 vol. \% CMs. It is clear seen that the pores are spherical and closed-cell and it is homogeneously distributed on the whole cross section homogeneously. The diameters of the pores mainly distribute in the narrow range of 1-2 $\mathrm{mm}$, which are much smaller and homogeneous than other reported closed-cell metal foams. Figure $1 \mathrm{~b}$ shows the representative morphology of CMs in the composite foams. It shows that CMs distribute independently in the cell wall and there is no sign of CMs cluster. Meanwhile, most of the CMs maintain their original appearance, despite a small part of them being broken and the fragments being easily observed. This is mainly due to the difference of thermal expansion coefficients between the CMs and the matrix, and the mechanical stirring process during the preparation procedures. It should also be noted that almost all of the CMs are penetrated by the magnesium matrix, meaning good bond strength between the CMs and the matrix.
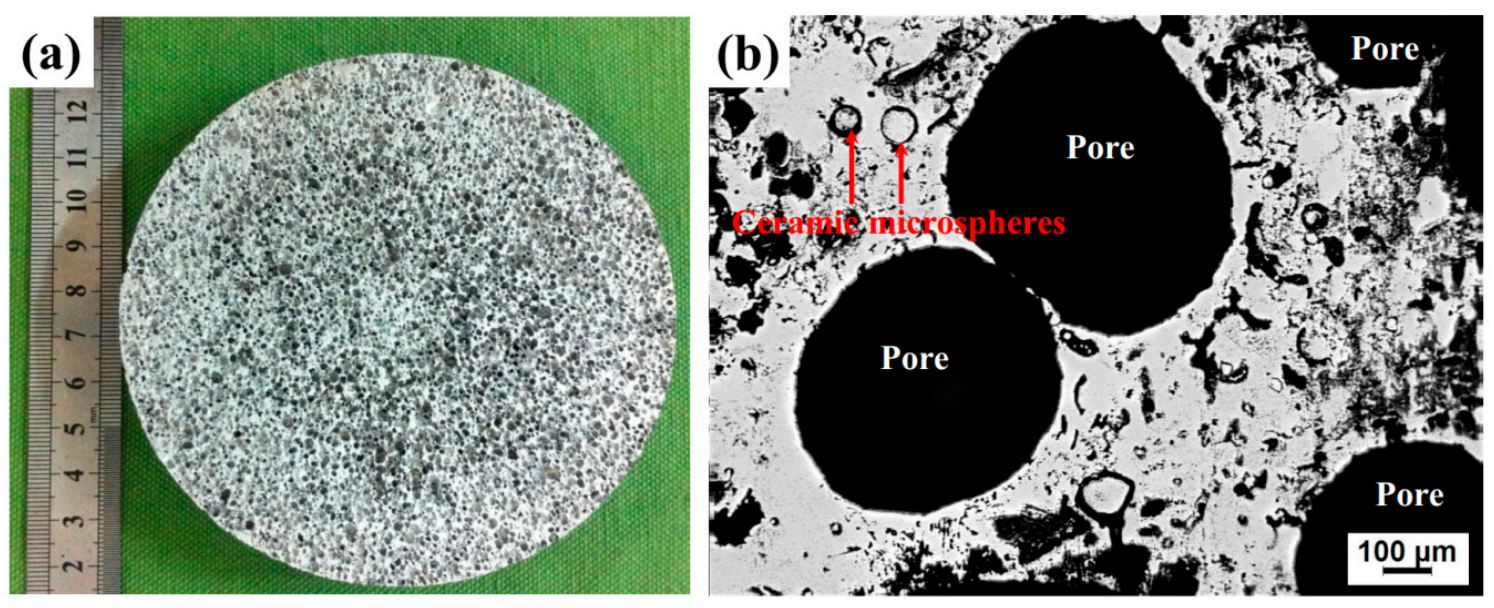

Figure 1. Cross section (a) and ceramic microspheres (CMs) morphology (b) in composite foams.

\subsection{Microstructure and Phase Composition}

Figure 2 shows the phase composition evolution of the composite foams under different heating conditions. It is clear that there are presently mainly five kinds of phases in all of the foams, that is $\alpha-\mathrm{Mg}, \beta-\mathrm{Mg}_{17} \mathrm{Al}_{12}, \mathrm{MgO}, \mathrm{Mg}_{2} \mathrm{Si}$, and $\mathrm{CaCO}_{3}$. The appearance of $\mathrm{Mg}_{2} \mathrm{Si}$ phase is due to the reaction between $\mathrm{CMs}$ and the matrix $[8-10,13] . \mathrm{CaCO}_{3}$ is from the undecomposed foaming agent. It can be seen that with the heating temperature increasing the peak intensity of $\beta-\mathrm{Mg}_{17} \mathrm{Al}_{12}$ decreases gradually, meaning that the content decreases. Figure 3 shows the typical morphology of $\beta-\mathrm{Mg}_{17} \mathrm{Al}_{12}$ and it can be seen that $\beta-\mathrm{Mg}_{17} \mathrm{Al}_{12}$ mainly distribute along the grain boundaries (Figure $3 \mathrm{a}$ ) with the typical morphologies of lamellar $\beta-\mathrm{Mg}_{17} \mathrm{Al}_{12}$ distributes around the bulk $\beta-\mathrm{Mg}_{17} \mathrm{Al}_{12}$ precipitates 
(Figure 3b) [14-16]. It should be underlined that no obvious $\beta-\mathrm{Mg}_{17} \mathrm{Al}_{12}$ phases were observed in traditional AZ31 magnesium foams [17-19], and the reasons will be discussed in Section 4. Figure 4 shows the evolution of $\beta-\mathrm{Mg}_{17} \mathrm{Al}_{12}$ at $320{ }^{\circ} \mathrm{C}$, it presents that part of bulk $\beta-\mathrm{Mg}_{17} \mathrm{Al}_{12}$ dissolves as the holding time increasing. As for the lamellar precipitates, part of them also dissolves into the matrix, leading to the content decrease along the grain boundaries. Also, it should not be ignored that $\beta-\mathrm{Mg}_{17} \mathrm{Al}_{12}$ appears in the grain interior. Figure 5 shows the effect of heating temperature on the microstructure evolution of the foams. It can be seen that under lower temperatures $\left(150{ }^{\circ} \mathrm{C}\right.$ and $250{ }^{\circ} \mathrm{C}$, Figure $5 \mathrm{a}, \mathrm{b}$ ) dissolution of the $\beta-\mathrm{Mg}_{17} \mathrm{Al}_{12}$ is not evident. While, increasing the temperature to $320^{\circ} \mathrm{C}$, lamellar precipitates start to dissolve (Figure $5 \mathrm{c}$ ). Further increasing the temperature to $400{ }^{\circ} \mathrm{C}$, the lamellar precipitates almost completely dissolve and the coarse precipitates begin to crack (Figure $5 \mathrm{~d}$ ), and it can be clearly seen that $\beta-\mathrm{Mg}_{17} \mathrm{Al}_{12}$ precipitates completely dissolve when the foams are heated at $500{ }^{\circ} \mathrm{C}$ (Figure 5e).

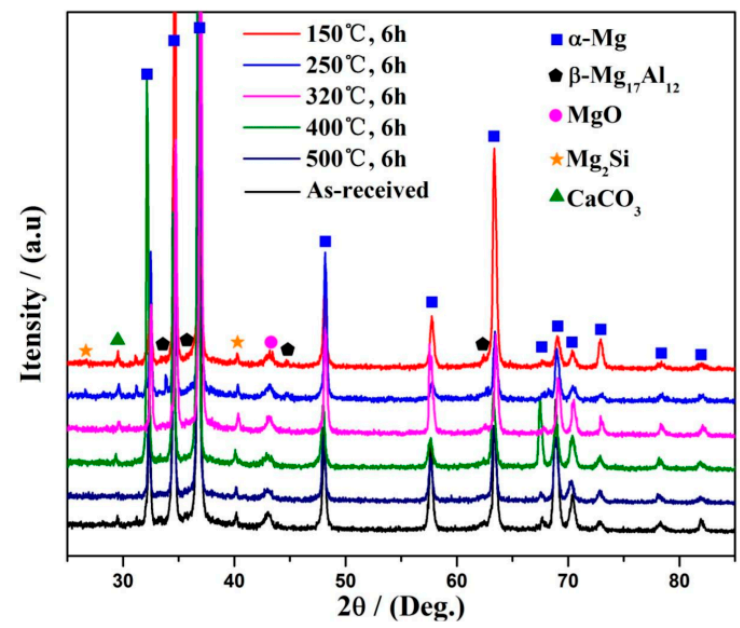

Figure 2. Phase compositions of AZ31B magnesium composite foams with CMs.
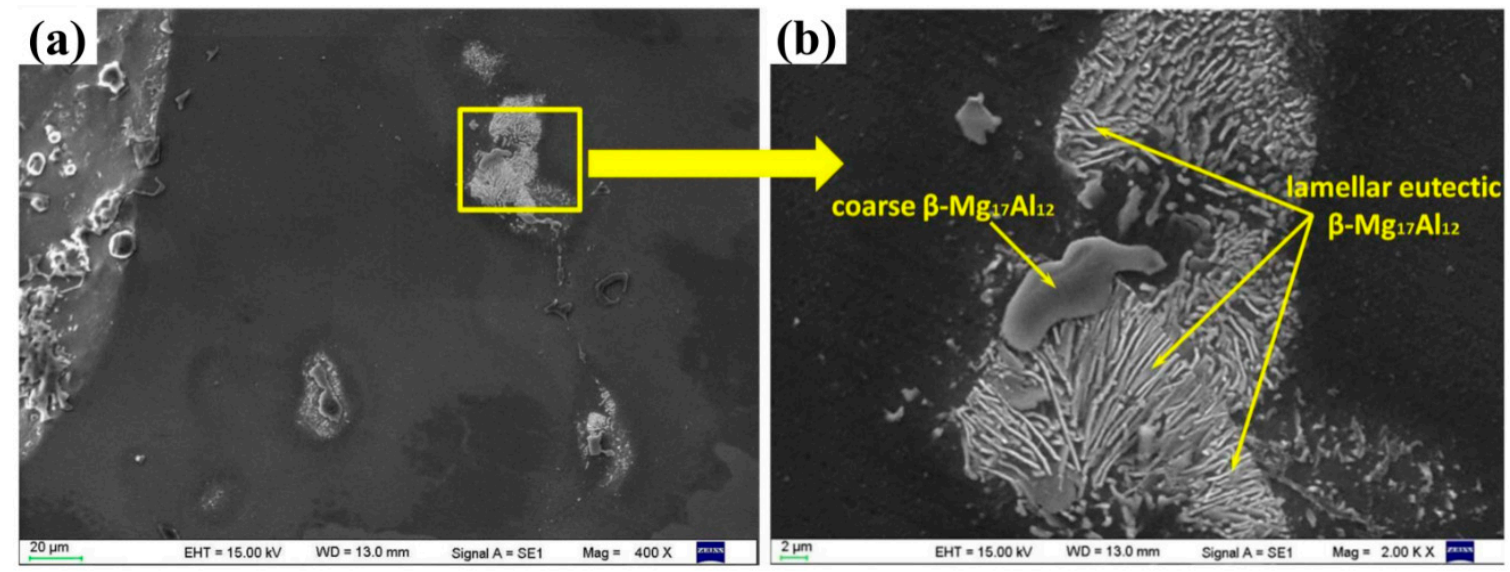

Figure 3. Morphologies of $\beta-\mathrm{Mg}_{17} \mathrm{Al}_{12}$ (a) and the enlarged image of $\beta-\mathrm{Mg}_{17} \mathrm{Al}_{12}$ (b) in the composite foams. 

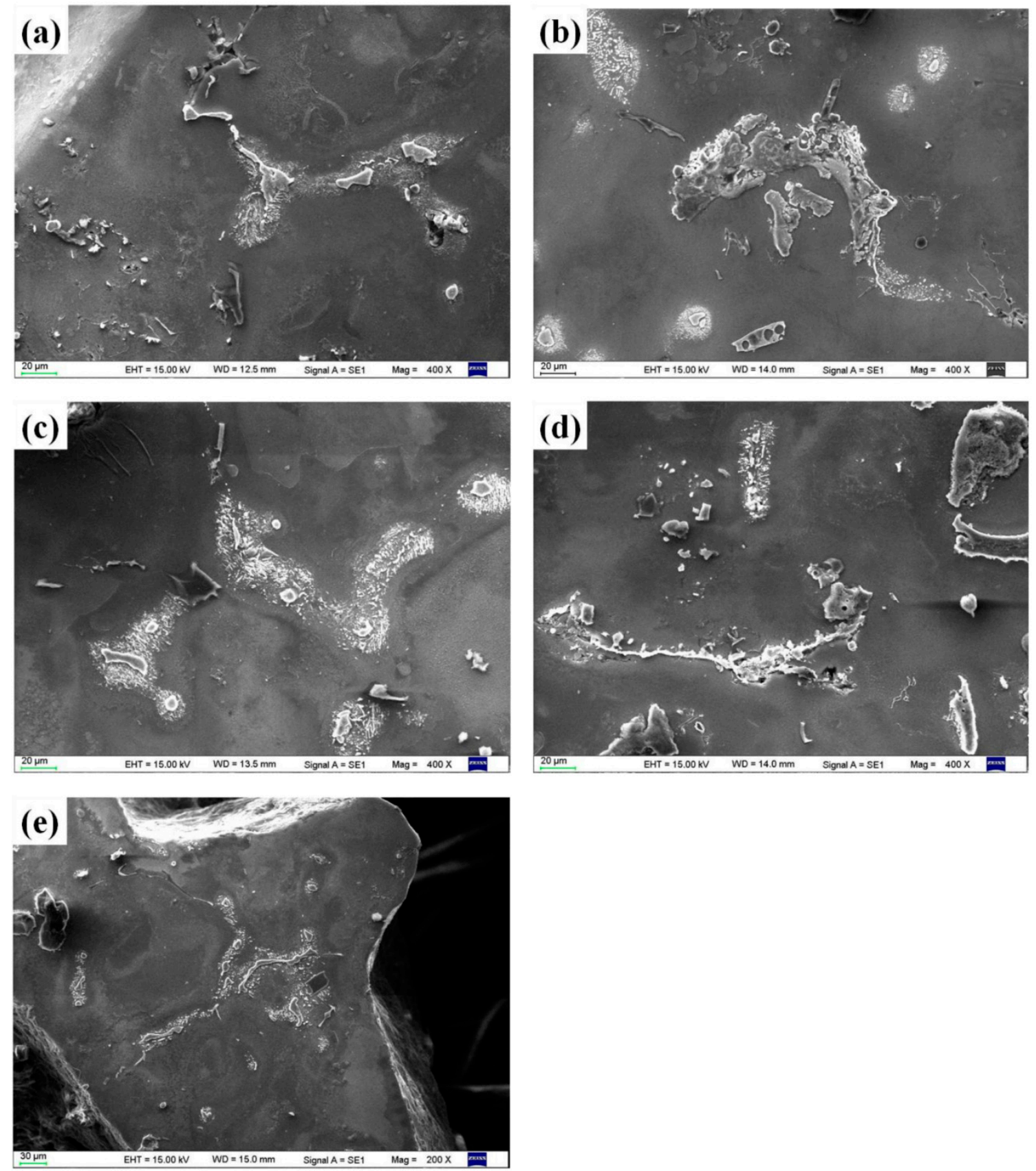

Figure 4. Morphology evolution of $\beta-\mathrm{Mg}_{17} \mathrm{Al}_{12}$ in the composite foams heated at $320^{\circ} \mathrm{C}$ for different holding times: (a) $1 \mathrm{~h}$, (b) $2 \mathrm{~h}$, (c) $4 \mathrm{~h}$, (d) $6 \mathrm{~h}$, and (e) $24 \mathrm{~h}$. 

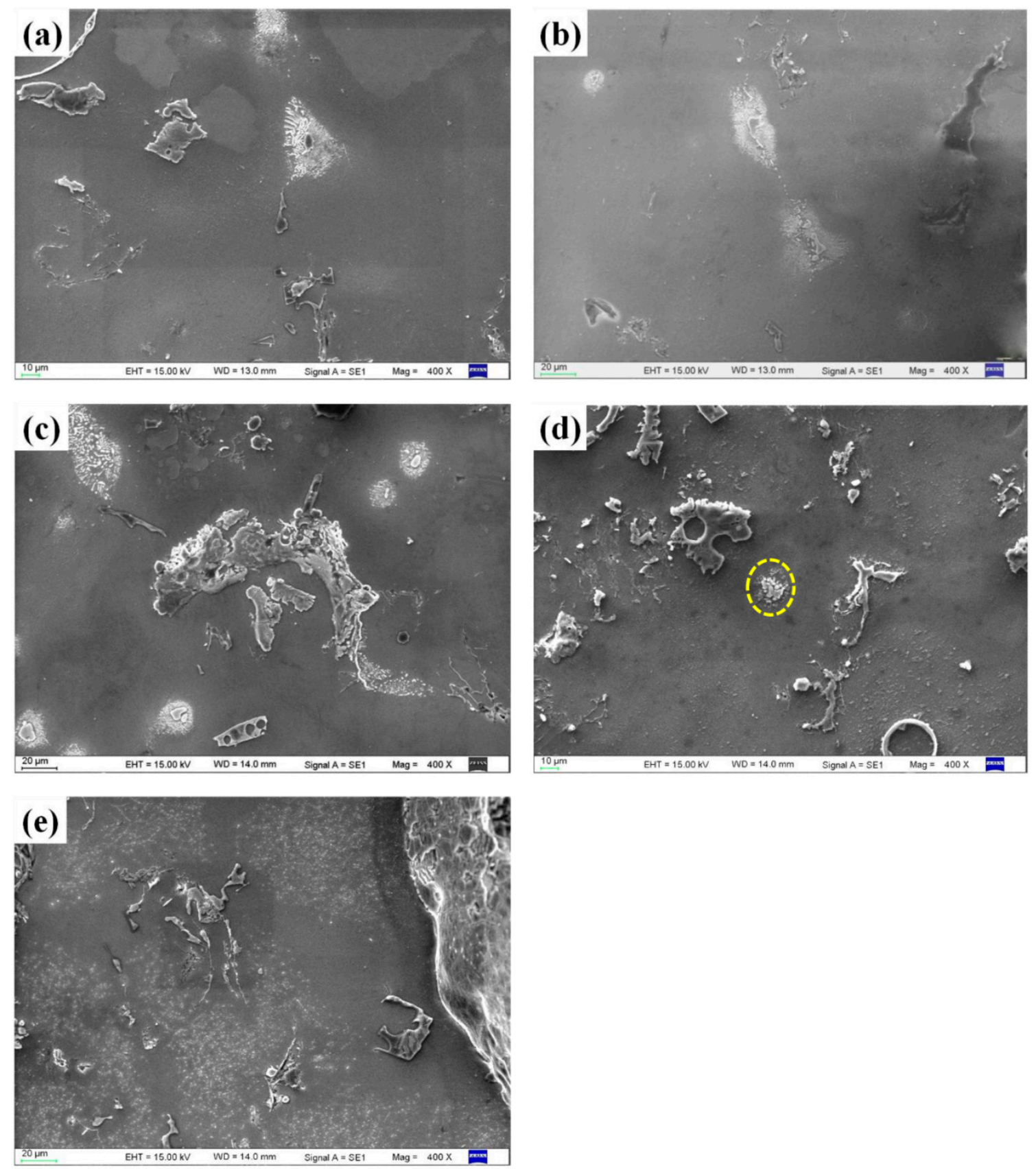

Figure 5. Morphology evolution of $\beta-\mathrm{Mg}_{17} \mathrm{Al}_{12}$ in the composite foams heated for $2 \mathrm{~h}$ with different heating temperatures: (a) $150{ }^{\circ} \mathrm{C}$, (b) $250{ }^{\circ} \mathrm{C}$, (c) $320^{\circ} \mathrm{C}$, (d) $400{ }^{\circ} \mathrm{C}$, and (e) $500{ }^{\circ} \mathrm{C}$.

\subsection{Micro-Hardness}

As shown in Figure 6, the thermal treatment can significantly influence the micro-hardness of the composite foams. It can be seen that thermal treatment lowers the micro-hardness of the foams when compared with the as-received foam. Typically, for the foams that are treated $150{ }^{\circ} \mathrm{C}$, the micro-hardness drops sharply after heating for $2 \mathrm{~h}$ and then decreases to the lowest level at $4 \mathrm{~h}$. As for the foams that are heated at $250{ }^{\circ} \mathrm{C}$, the lowest micro-hardness value presents at $2 \mathrm{~h}$. While, for the foams heated at $320^{\circ} \mathrm{C}$ to $500{ }^{\circ} \mathrm{C}$, the hardness values increase gradually with extension of the holding time from 1 to $24 \mathrm{~h}$. Meanwhile, it can be found that with the heating time increasing, the difference of micro-hardness values between the foams gradually become smaller. Specially, 
the micro-hardness values of the foams that are heated for $24 \mathrm{~h}$ are almost the same and are slightly higher than the as-received foams, except for the foams heated at $150{ }^{\circ} \mathrm{C}$.

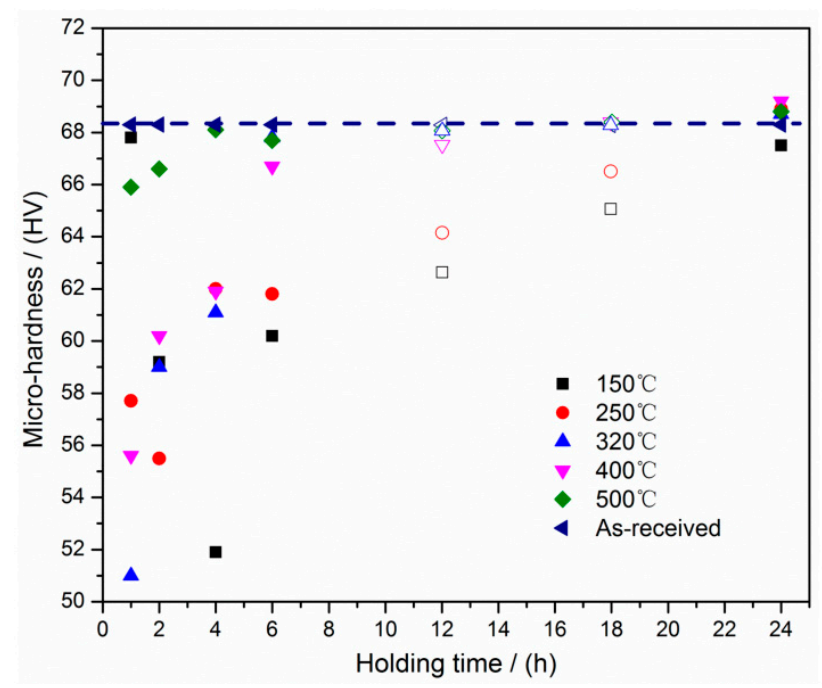

Figure 6. Micro-hardness evolution of the foams.

\subsection{Compression Characteristics}

Representative compressive stress-strain curves of the foams under different heating conditions are shown in Figure 7. It can be seen that the thermal treatment process has no obvious influence on the whole tendency of the curves, and there are three typical deformation stages that can be also found elsewhere [10-12,17,20,21]: linear deformation stage, yielding plateau stage, and densification stage. It can be clearly seen from Figure 7 that for almost all of the specimens, the yielding plateau stages are smooth without big fluctuation or serrations. Two reasons are responsible for this phenomenon. One is the small pore size (as shown in Figure 1) of the foams due to the introduction of $\mathrm{Mg}_{2} \mathrm{Si}$ (reaction product of CMs and magnesium melt) phases, which can also act as the nucleation particles of bubbles besides Ca granule [2,10]. Accordingly, the change of compression stress is very small when one layer of cells is crushed because the strength of each single cell is small [20]. Another is that the foam edge will flake away during crushing, which will decrease the support of samples, and thus will stop the stress from increasing when the specimens are compressed [21]. It also should be noted from Figure 7a that the yield stress and the plateau stress [17] of the foams heated at $320{ }^{\circ} \mathrm{C}$ gradually increase with time increasing, and the yield stresses of the foams treated for $6 \mathrm{~h}$ and $24 \mathrm{~h}$ are nearly equal to that of the unheated foam. Figure $7 \mathrm{~b}$ reveals that heating temperature has an important effect on yield stress and plateau stress. With lower temperatures $\left(150{ }^{\circ} \mathrm{C}, 250{ }^{\circ} \mathrm{C}, 320^{\circ} \mathrm{C}\right.$, and $\left.400{ }^{\circ} \mathrm{C}\right)$, both of the stresses change little. While, for the foams that were treated at $500{ }^{\circ} \mathrm{C}$, the yield stress and plateau stress are significantly improved with the same holding time of $2 \mathrm{~h}$. To clearly describe the variation, the yield stress of the foams treated under different conditions is measured and the results are shown in Figure 8. It can be seen that all of the yield stresses are lower than that of the as-received foams, except for the foams that were heated for $24 \mathrm{~h}$. Meanwhile, yield stresses for the foams treated at $150{ }^{\circ} \mathrm{C}$ and $250{ }^{\circ} \mathrm{C}$ decrease to the lowest level with the endure time of $4 \mathrm{~h}$ and $2 \mathrm{~h}$, respectively, just like the tendency of corresponding micro-hardness (Figure 6). While, for the foams that were treated at $320{ }^{\circ} \mathrm{C}$, $400{ }^{\circ} \mathrm{C}$, and $500{ }^{\circ} \mathrm{C}$, yield stresses gradually increase with enduring time increasing. Without exception, the maximum yield stress for all of the foam can be obtained with a holding time of $24 \mathrm{~h}$. 

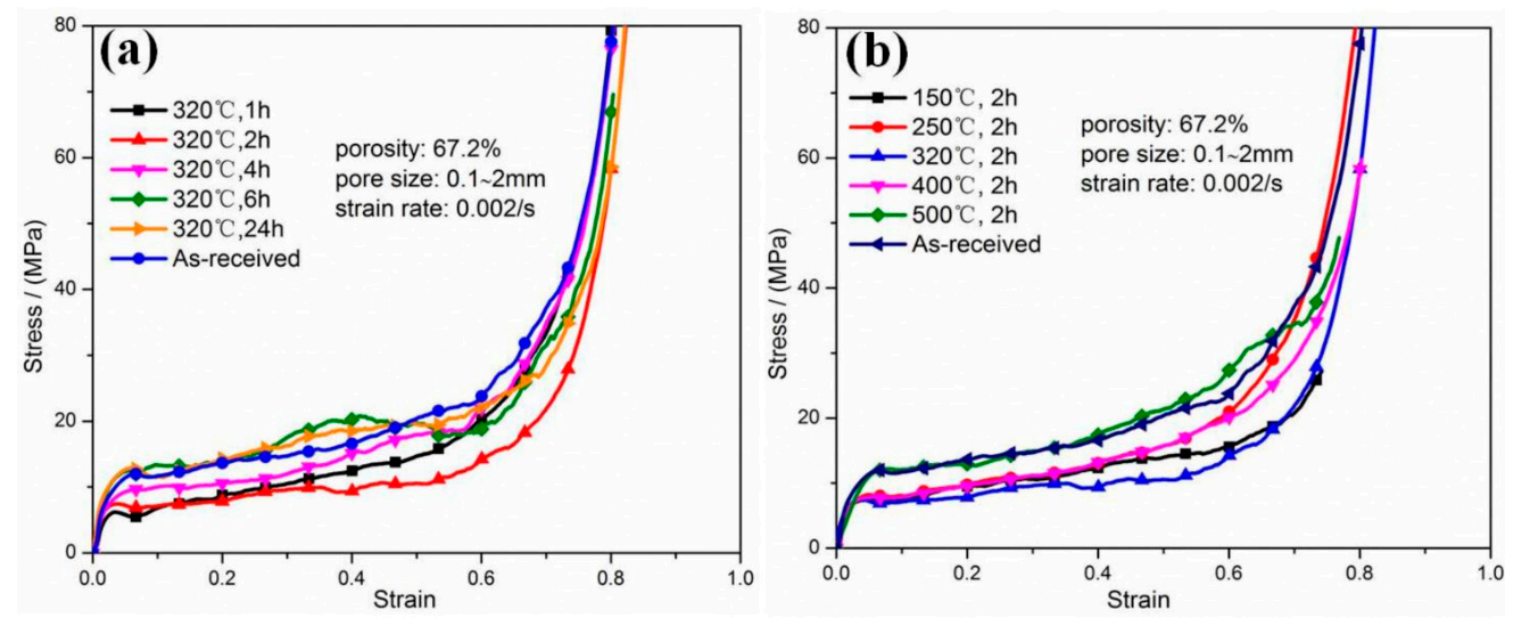

Figure 7. Compressive stress-strain curves of the composites foams: (a) heated at $320{ }^{\circ} \mathrm{C}$ with different holding times, and (b) foams with enduring time of $2 \mathrm{~h}$ at different heating temperatures.

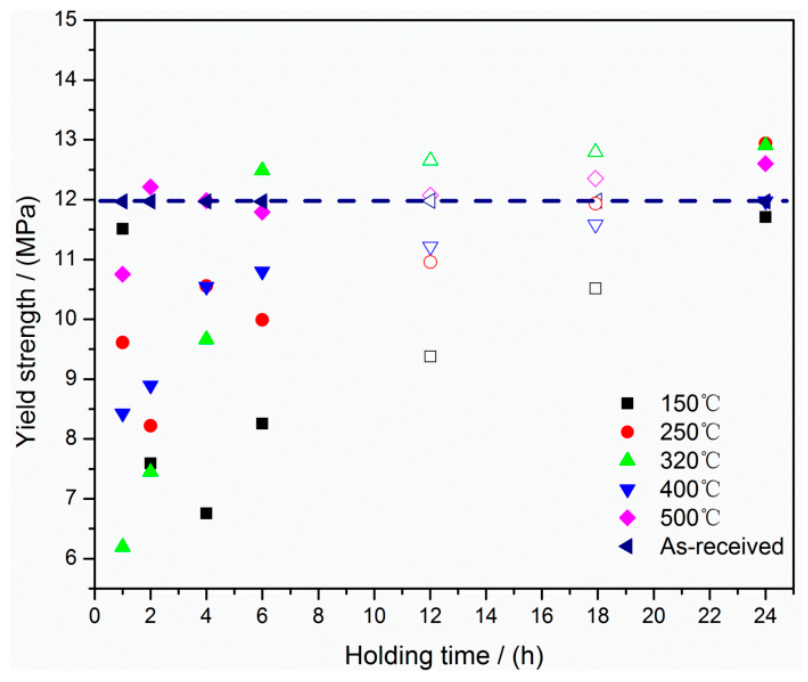

Figure 8. Compressive yield strength of foams under different conditions.

Figure 9a presents the densification strains of the foams treated under different conditions [6]. It is clear that thermal treatment enhances the densification strain of the foams. Mean plateau strength is a unique characteristic of metallic foams [17], and in this work, it is defined as the average stress with the strain from the yield strain to densification strain. Figure $9 \mathrm{~b}$ shows the mean plateau strength of the foams treated with different temperatures and times. It can be seen that, to majority of the thermal treated foams, mean plateau strength are lower than that of the as-received foams (the dash line). As for the energy absorption capacities of the foams, it can be calculated according to Equation (2), and the results are shown in Figure 9c:

$$
W=\int_{0}^{\varepsilon} \sigma d \varepsilon
$$

while $W$ is energy absorption capacity and $\sigma$ is the stress where the strain is $\varepsilon$ [17]. It shows from Figure $9 \mathrm{c}$ that thermal treatment process lowers the energy absorption capacity and the variation tendency is consistent with the plateau strength, meaning that plateau strength is a main factor that dominates the energy absorption capacity of foams when the densification strains are similar. Thus, it is very significant to improve the plateau strength to obtain excellent energy absorption capacity for metal foams when a specific densification strain is given. 

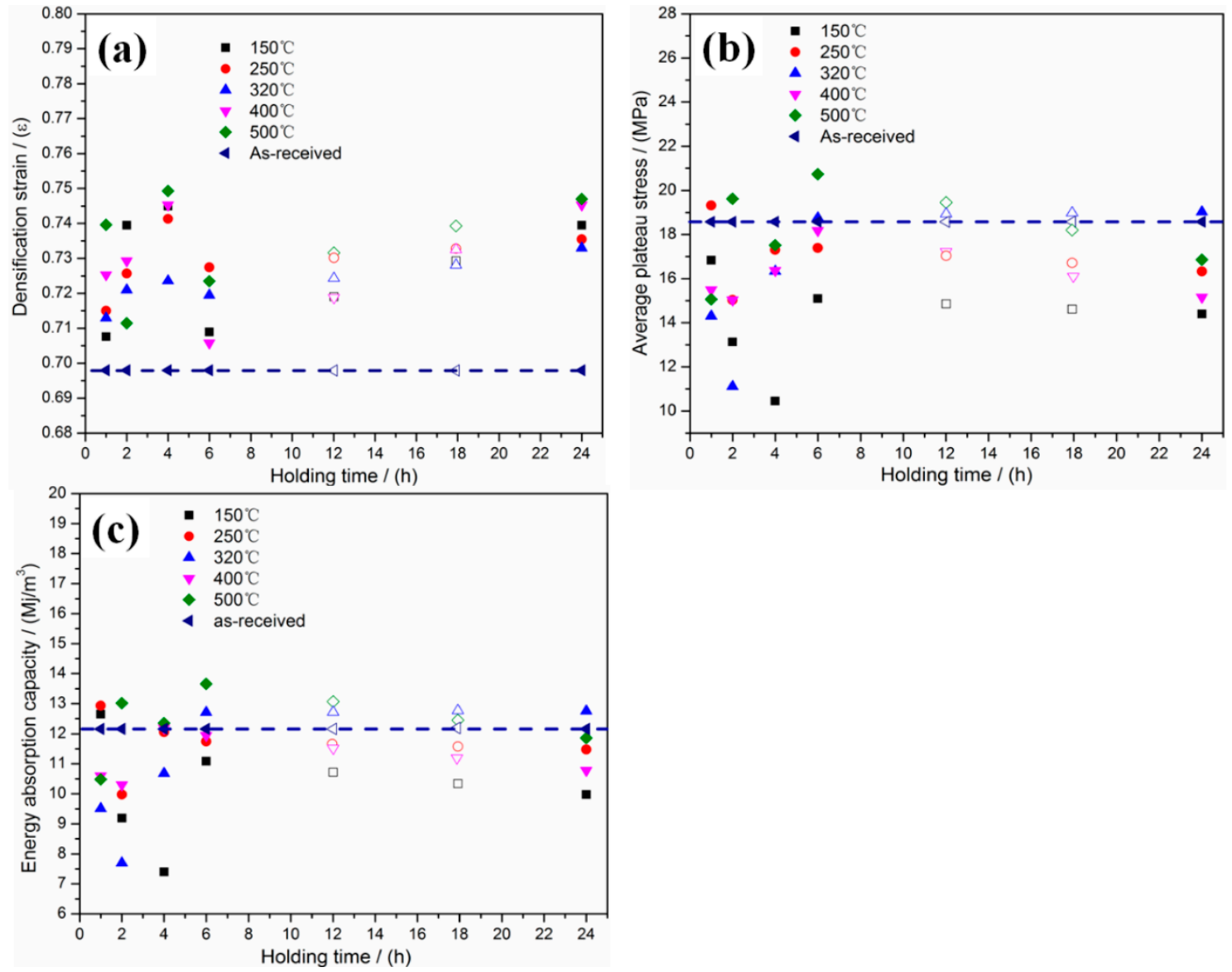

Figure 9. Densification strain (a), average plateau stress (b) and energy absorption capacity (c) of the foams.

\subsection{Strain Hardening Exponent}

Strain hardening capability is important for the selection of metallic materials, which can be expressed by strain hardening exponent [22-25]. When compared to the flow stress and ultimate strength, the strain hardening exponent can reflect the strain hardening behavior of materials more directly [26]. It can be calculated by Equation (3) [27]:

$$
\sigma=K \varepsilon^{n}
$$

where $\sigma$ is true stress, $K$ is strength coefficient, $\varepsilon$ is true plastic strain, and $n$ is strain hardening exponent. The value of $K$ and $n$ can be obtained experimentally by plotting the true stress-true strain curves. In log-log scale, a linear relationship should exist between the true stress and the true strain. The exponent $n$ corresponds to the angular coefficient of the line [28]. The trend of $\ln (\sigma)$ with $\ln (\varepsilon)$ and the value of $K$ and $n$ for the foams heated at $320^{\circ} \mathrm{C}$ and $2 \mathrm{~h}$ (as representative) are shown in Figure 10a,b, Tables 4 and 5, meanwhile, Figure 10c shows the strain hardening exponent value of all the related foams. It can be clearly seen from Figure 10c that the strain hardening exponent value for most of the heated foams are higher than the as-received foam. When compared to other foams, the foams that were heated for $24 \mathrm{~h}$ possess the lowest strain hardening exponent value. 

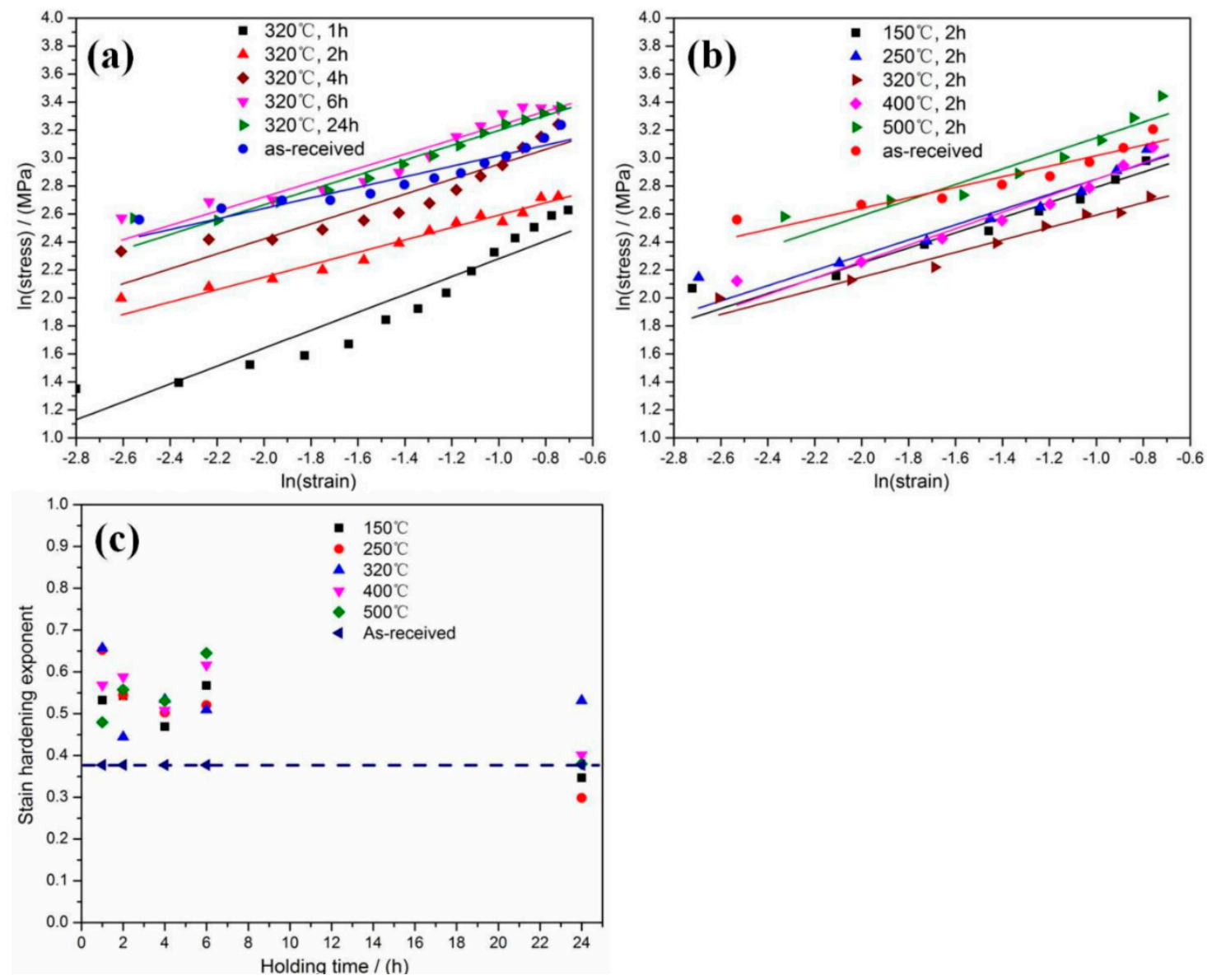

Figure 10. The $\ln \left(\right.$ stress)- $\ln \left(\right.$ strain) curves of the foams heated at $320^{\circ} \mathrm{C}(\mathbf{a})$, held for $2 \mathrm{~h}(\mathbf{b})$ and the strain hardening exponents of foams (c).

Table 4. The value of $K$ and $n$ of the foams heated at $320^{\circ} \mathrm{C}$.

\begin{tabular}{ccccccc}
\hline Holding Time & As-Received & $\mathbf{1} \mathbf{h}$ & $\mathbf{2} \mathbf{h}$ & $\mathbf{4} \mathbf{h}$ & $\mathbf{6} \mathbf{~ h}$ & $\mathbf{2 4} \mathbf{h}$ \\
\hline$K$ & 29.781 & 31.572 & 20.825 & 32.761 & 42.136 & 41.622 \\
$n$ & 0.377 & 0.657 & 0.444 & 0.534 & 0.509 & 0.531 \\
\hline
\end{tabular}

Table 5. The value of $K$ and $n$ of the foams held for $2 \mathrm{~h}$.

\begin{tabular}{ccccccc}
\hline Holding Temperature & As-Received & $\mathbf{1 5 0}{ }^{\circ} \mathbf{C}$ & $\mathbf{2 5 0}{ }^{\circ} \mathbf{C}$ & $\mathbf{3 2 0}{ }^{\circ} \mathbf{C}$ & $\mathbf{4 0 0}{ }^{\circ} \mathbf{C}$ & $\mathbf{5 0 0}^{\circ} \mathbf{C}$ \\
\hline$K$ & 29.781 & 28.048 & 29.780 & 20.825 & 31.049 & 40.548 \\
$n$ & 0.377 & 0.543 & 0.544 & 0.444 & 0.588 & 0.558 \\
\hline
\end{tabular}

\section{Discussion}

Due to the unique structure and low thermal conductivity, cooling rates of magnesium composite foam vary in different places during the solidification process, resulting in internal casting stress. In addition, the different thermal conductivity and heat diffusivity between CMs and the matrix will also cause internal stress. Internal stress relaxation is governed by a thermal activated mechanism, which can be described by the Zener-Wert-Avrami relationship as the following equation shows [29-31]:

$$
\sigma_{T, t}^{I S} / \sigma_{0}^{I S}=\exp \left[-(A t)^{m}\right]
$$


where $\sigma_{0}^{I S}$ is the internal stress of the as-received $\mathrm{Mg}$ composite foams, $\sigma_{T, t}^{I S}$ is the internal stress of the samples heated at the temperature of $T$ for time $t$, and $m$ is a constant relating to internal stress relaxation mechanism. $A$ is a function depending on the material and heating temperature that is based on Equation (5):

$$
A=B \exp \left(-\frac{\Delta H}{k T}\right)
$$

where $B$ is material constant, $k$ is the Boltzmann constant, $\Delta H$ is the activation enthalpy for actual stress relaxation. It can be seen from Equations (4) and (5) that the higher heating temperature $(T)$ or longer holding time $(t)$, the greater relaxation of internal stresses. It has been reported that residual stresses in WC and Co phases decrease with both heating temperature and annealing time increasing, and finally, the residual stresses decline to a very small value that became a stable state [29]. With regard to this work, it can be clearly seen that for the foams heated at $150{ }^{\circ} \mathrm{C}$, the internal stress should be eliminated at $4 \mathrm{~h}$, resulting in the lowest micro-hardness and yield strength. While, for the foams that were heated at $250{ }^{\circ} \mathrm{C}$, the micro-hardness and yield strength decreased to the lowest value at $2 \mathrm{~h}$. Moreover, it was shown from Figures 6 and 8 that the foams heated at $320^{\circ} \mathrm{C}, 400{ }^{\circ} \mathrm{C}$, and $500{ }^{\circ} \mathrm{C}$ possess the lowest micro-hardness and yield strength when the holding time was $1 \mathrm{~h}$. It was obviously indicated that the internal stress was released more efficiently at higher temperature, which was consistent with the reported literature [29-31]. While, it is reasonable to infer that the lowest value can be actually yielded with the holding time less than $1 \mathrm{~h}$ when the heating temperature is higher than $320^{\circ} \mathrm{C}$.

In consideration of $\beta-\mathrm{Mg}_{17} \mathrm{Al}_{12}$ phases, it has been known that the amounts of $\beta-\mathrm{Mg}_{17} \mathrm{Al}_{12}$ phase can be negligible in AZ31B magnesium alloy due to the low Al content [19]. However, in this work, $\beta-\mathrm{Mg}_{17} \mathrm{Al}_{12}$ is detected in AZ31B magnesium composite foams (as shown in Figures 4 and 5). DSC detections were applied to reveal this differential and the result is shown in Figure 11 . It can be seen from Figure 11 that $\mathrm{Zn}$-rich and $\mathrm{Mg}_{17} \mathrm{Al}_{12}$ endothermic peaks are observed in the magnesium composite foams, while they are not detected in the foams without CMs. It is illustrated that the addition of CMs changes solidification behavior of the melt. Specially, for the foams with CMs, ceramic microspheres, eutectic phases, and other intermetallic compounds are pushed to grain boundaries by the primary magnesium phase during the solidification process. In addition, the thermal conductivity and the heat diffusivity of $\mathrm{CMs}$ are lower than that of $\mathrm{Mg}$ matrix, causing the melt temperatures around CMs are higher than the primary magnesium phase distance away from CMs [8]. All of this resulted that grain boundaries are the last freezing regions. Meanwhile, with the addition of CMs, the solutes in magnesium melt, such as $\mathrm{Zn}, \mathrm{Al}$, etc., are more easily segregated at the grain boundaries, resulting in the eutectic reaction and the appearance of $\mathrm{Zn}$-rich and $\mathrm{Mg}_{17} \mathrm{Al}_{12}$ phases. It can be also revealed that the melting point of the $\mathrm{Zn}$-rich and $\mathrm{Mg}_{17} \mathrm{Al}_{12}$ phases are about $341^{\circ} \mathrm{C}$ and $394{ }^{\circ} \mathrm{C}$ (Figure 11), respectively. It has been known that the melting point of pure $\mathrm{Zn}$ is $419.5^{\circ} \mathrm{C}$ and $\mathrm{Mg}_{17} \mathrm{Al}_{12}$ is $426^{\circ} \mathrm{C}$, which are higher than the measured values in this work. This is due to that $\mathrm{Al}, \mathrm{Ca}$, and other solutes infiltrate into the $\mathrm{Zn}$-rich phase, leading to the decrease of the melting point. Also, it has been confirmed that the appearance of the $\mathrm{Zn}$-rich phase will result in the melting point decrease of $\mathrm{Mg}_{17} \mathrm{Al}_{12}$ [15].

$\mathrm{Up}$ to now, the fracture mechanisms of $\mathrm{Mg}$ composites with ceramic microspheres are still unclear $[8,32,33]$. In this work, we mainly focus on the influence of $\beta-\mathrm{Mg}_{17} \mathrm{Al}_{12}$ on the fracture of AZ31 magnesium composite foams, and meanwhile found that the other phases (including CMs) are relatively thermal stable, as described above. It has been proved that the amount, distribution, and morphology of $\beta-\mathrm{Mg}_{17} \mathrm{Al}_{12}$ phase play an important role on crack formation and fracture in $\mathrm{AZ}$ series magnesium alloys [34]. In addition, it has been confirmed that $\mathrm{Mg} / \mathrm{Mg}_{17} \mathrm{Al}_{12}$ interface often acted as crack initiation sources, owing to the incompatible crystal structure between $\mathrm{Mg}$ (h.c.p. structure) and $\mathrm{Mg}_{17} \mathrm{Al}_{12}$ (b.c.c. structure), leading to the deterioration of mechanical properties $[14,35,36]$. However, when alloys are subjected to some heat treatment, coarse $\beta-\mathrm{Mg}_{17} \mathrm{Al}_{12}$ precipitates distribute along the grain boundaries could be transformed to fine continuous precipitates that distributed in grains, resulting in the enhancement of mechanical properties [14]. In this work, crack initiation process 
can be sketched, as in Figure 12. For the as-received composite foams, discontinuous $\beta-\mathrm{Mg}_{17} \mathrm{Al}_{12}$ phases distribute along grain boundaries (Figure 12a). During the compression process, the normal stress $\left(\mathrm{F}_{1}\right)$ and shear stress $\left(\mathrm{F}_{2}\right)$ exist simultaneously for a single grain. Shear stress will impact the grain boundaries all the time due to the inconsistent orientations between the grains and the compression direction. With the compression stress $(\mathrm{F})$ increasing, the shear stress $\left(\mathrm{F}_{2}\right)$ increases. Accordingly, the cracks will initiate at the interface of precipitate/grain and ultimately propagate, leading to the fracture of the foams. However, when the foams are heated at different conditions (for example $500{ }^{\circ} \mathrm{C}$, $24 \mathrm{~h}), \beta-\mathrm{Mg}_{17} \mathrm{Al}_{12}$ phases are dissolved and are transformed to lath-shaped continuous precipitates that distribute in grains (Figure 12b), and the occurrence probability of cracks significantly decrease, leading to the improved yield strength.

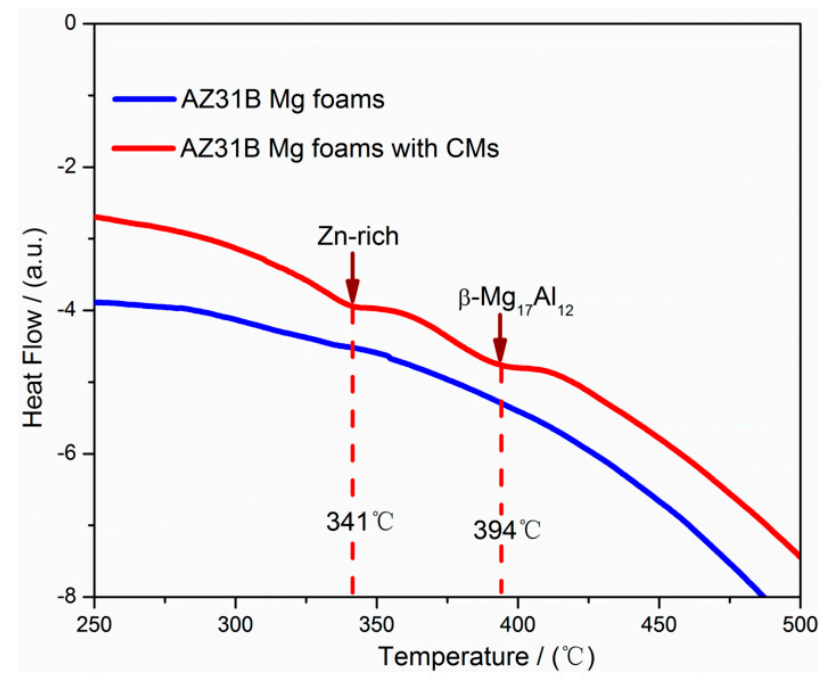

Figure 11. Differential scanning calorimeter (DSC) results of AZ31B foams with and without CMs.
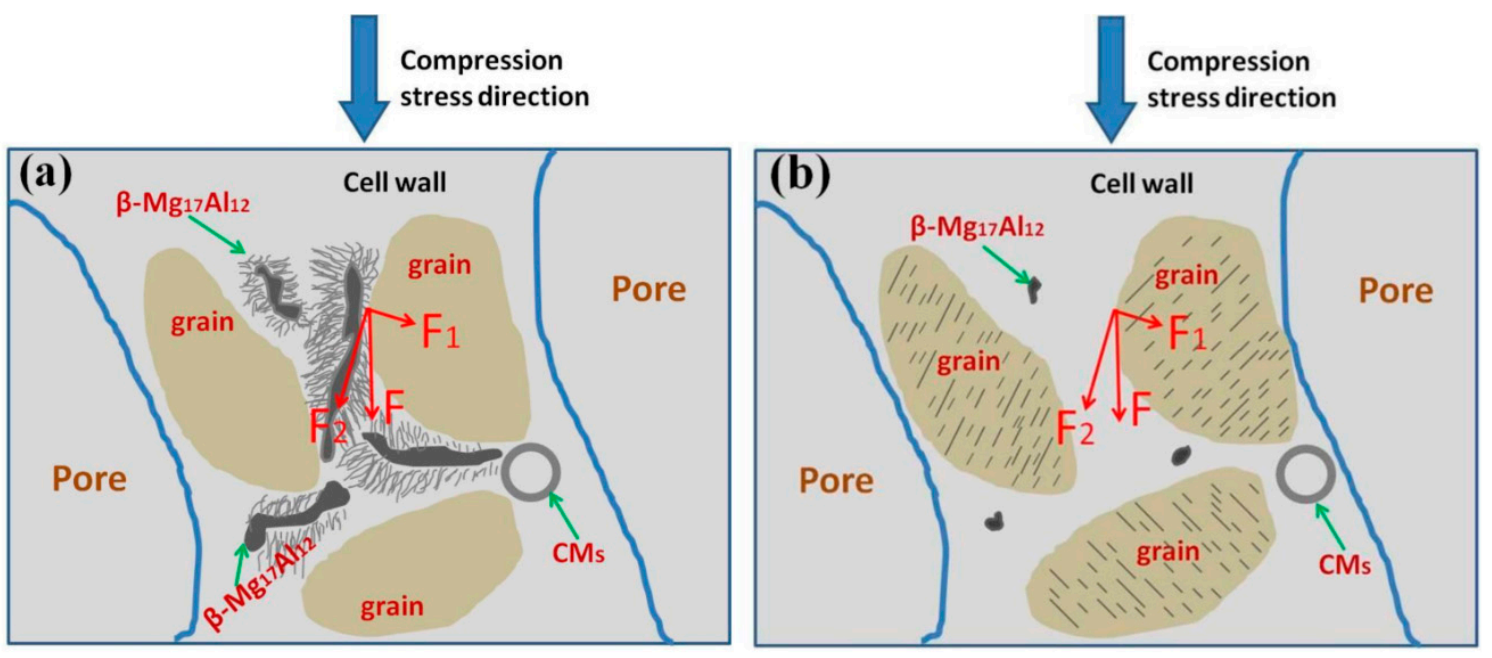

Figure 12. Schematic diagram of the generation of cracks in the unheated (a) and heated (b) composite foams.

During thermal treatment process, $\mathrm{Zn}$-rich and $\mathrm{Mg}_{17} \mathrm{Al}_{12}$ phases tend to dissolve, and $\mathrm{Zn}$ and $\mathrm{Al}$ solutes are gradually diffused into the Mg matrix. Diffusion efficiency of solutes can be expressed by the Arrhenius equation [37]:

$$
D=D_{0} \exp \left(-\frac{Q}{R T}\right)
$$


where $D$ is diffusion coefficient, $D_{0}$ is diffusion constant, $Q$ is diffusion activation energy, $T$ is thermodynamic temperature, and $R$ is the mole gas constant. It can be seen from Equation (6) that the atom diffusion coefficient is larger at a higher temperature, leading to a more homogeneous distribution of solutes in the matrix, as well as more efficient of solution strengthening effect. That is why the micro-hardness and yield strength of the foams that were heated at $500{ }^{\circ} \mathrm{C}$ are higher than other foams with the same holding times. Under the present conditions, the combined effects of solution strengthening effect and the relief of internal stress are responsible for the evolution of micro-hardness and yield strength. Internal stress relief effect is more evident than the solution strengthening effect when the foams are heated at $320{ }^{\circ} \mathrm{C}, 400{ }^{\circ} \mathrm{C}, 500{ }^{\circ} \mathrm{C}$ for $1 \mathrm{~h}, 250{ }^{\circ} \mathrm{C}$ for $2 \mathrm{~h}$, and $150{ }^{\circ} \mathrm{C}$ for $4 \mathrm{~h}$, respectively, resulting in the decrease of yield strength and micro-hardness. While, with the holding time increasing, the solution strengthening effect dominates the mechanical properties, leading to the gradual increase of micro-hardness and yield strength (Figures 6 and 8).

\section{Conclusions}

In this work, AZ31B magnesium composite foams with CMs are treated with different heating temperatures and enduring times. Meanwhile, the superposition effect on the microstructure and compressive properties of the foams are investigated, and the conclusions are as follows:

(1) With the addition of $\mathrm{CMs}$ and $\mathrm{Ca}$, obvious $\beta-\mathrm{Mg}_{17} \mathrm{Al}_{12}$ phases are detected in $\mathrm{AZ31B}$ magnesium composite foams, which is due to the changes of solidification behaviors of AZ31B melt that is caused by CMs and Ca.

(2) With heating temperature and enduring time increasing, $\beta-\mathrm{Mg}_{17} \mathrm{Al}_{12}$ phases gradually dissolve into the matrix, resulting in solution strengthening effect. While the release of internal stress leads to the decrease of the compressive strength and the micro-hardness of the foams. Their combined effect is responsible for the evolution of mechanical properties under the experimental conditions.

(3) When comparing with the unheated foams, almost all of the heated composite foams possess higher strain hardening exponents, while exhibiting lower micro-hardness, yield strength, and energy absorption capacity.

Furthermore, ore factors should be taken into account when the magnesium composite foams, which experienced different temperature-time superposition effect, are used in the practical application.

Author Contributions: X.X., J.D. and X.C. conceived and designed the study; J.W. and Y.P. performed the experiments; N.W. performed the literature search; X.H. and C.Q. made the figures; J.W. and Y.P. analyzed the data and wrote the paper with the support of X.X., J.D. and X.C.

Acknowledgments: The present authors are thankful for the financial support provided by the National Natural Science Foundation of China (Granted No. 51325401, 51501053 and U1660201), the National High Technology Research and Development Program of China (Granted No. 2015AA042504), Science and Technology Plan Projects of Hebei Province (No. 15211026) and Postgraduate Innovation Project of Hebei Province.

Conflicts of Interest: The authors declare no conflict of interest.

\section{References}

1. Mondal, D.P.; Majumder, J.D.; Jha, N.; Badkul, A.; Das, S.; Patel, A. Titanium-cenosphere syntactic foam made through powder metallurgy route. Mater. Des. 2012, 34, 82-89. [CrossRef]

2. Wang, J.; Zhang, Z.; Jiang, Q.; Xia, X.C.; Qiu, C.R.; Ding, J.; Zhao, W.M. A novel bubble nucleation particle for magnesium composite foam. Mater. Lett. 2017, 193, 187-190. [CrossRef]

3. Tao, X.F.; Zhang, L.P.; Zhao, Y.Y. Al matrix syntactic foam fabricated with bimodal ceramic microspheres. Mater. Des. 2009, 30, 2732-2736. [CrossRef]

4. Orbulov, I.N. Compressive properties of aluminium matrix syntactic foams. Mater. Sci. Eng. A 2012, 555, 52-56. [CrossRef]

5. Xia, X.C.; Chen, X.W.; Zhang, Z.; Chen, X.; Zhao, W.M.; Liao, B.; Hur, B.Y. Compressive properties of closed-cell aluminum foams with different contents of ceramic microspheres. Mater. Des. 2014, 56, 353-358. [CrossRef] 
6. Gupta, N.; Luong, D.D.; Cho, K. Magnesium matrix composite foams-Density, mechanical properties, and applications. Metals 2012, 2, 238-252. [CrossRef]

7. Hartmann, M.; Reindel, K.; Singer, R.F. Fabrication and properties of syntactic magnesium foams. MRS Proc. 1998, 521. [CrossRef]

8. Daoud, A.; El-Khair, M.T.A.; Abdel-Aziz, M.; Rohatgi, P. Fabrication, microstructure and compressive behavior of ZC63 Mg-microballoon foam composites. Compos. Sci. Technol. 2007, 67, 1842-1853. [CrossRef]

9. Steinacher, M.; Mrvar, P.; Zupanič, F. Interaction between AE44 magnesium alloy and $\mathrm{SiC}_{-} \mathrm{Al}_{2} \mathrm{O}_{3}-\mathrm{SiO}_{2}$ ceramic foam. Trans. Nonferr. Met. Soc. China 2015, 25, 1011-1019. [CrossRef]

10. Xia, X.C.; Feng, J.L.; Ding, J.; Song, K.H.; Chen, X.W.; Zhao, W.M.; Liao, B.; Hur, B.Y. Fabrication and characterization of closed-cell magnesium-based composite foams. Mater. Des. 2015, 74, 36-43. [CrossRef]

11. Huang, L.; Wang, H.; Yang, D.H.; Ye, F.; Lu, Z.P. Effects of scandium additions on mechanical properties of cellular al-based foams. Intermetallics 2012, 28, 71-76. [CrossRef]

12. Yang, D.H.; Hur, B.Y.; Yang, S.R. Study on fabrication and foaming mechanism of $\mathrm{Mg}$ foam using $\mathrm{CaCO}_{3}$ as blowing agent. J. Alloys Compd. 2008, 461, 221-227. [CrossRef]

13. Huang, Z.Q.; Yu, S.R. Microstructure characterization on the formation of in situ $\mathrm{Mg}_{2} \mathrm{Si}$ and $\mathrm{MgO}$ reinforcements in AZ91D/Flyash composites. J. Alloys Compd. 2011, 509, 311-315. [CrossRef]

14. Xu, S.W.; Matsumoto, N.; Kamado, S.; Honma, T.; Kojima, Y. Effect of $\mathrm{Mg}_{17} \mathrm{Al}_{12}$ precipitates on the microstructural changes and mechanical properties of hot compressed AZ91 magnesium alloy. Mater. Sci. Eng. A 2009, 523, 47-52. [CrossRef]

15. Kim, J.M.; Park, B.K.; Jun, J.H.; Shin, K.; Kim, K.T.; Jung, W.J. Microstructure and heat resistance of Mg-Al-Zn alloys containing metastable phase. Mater. Sci. Eng. A 2007, 449-451, 326-329. [CrossRef]

16. Xu, S.W.; Matsumoto, N.; Kamado, S.; Honma, T.; Kojima, Y. Dynamic microstructural changes in Mg-9Al-1Zn alloy during hot compression. Scr. Mater. 2009, 61, 249-252. [CrossRef]

17. Xia, X.; Zhao, W.; Feng, X.; Feng, H.; Zhang, X. Effect of homogenizing heat treatment on the compressive properties of closed-cell Mg alloy foams. Mater. Des. 2013, 49, 19-24. [CrossRef]

18. Xia, X.C.; Chen, X.W.; Zhao, W.M.; Xue, H.T.; Liao, B.; Hur, B.Y.; Wang, Z.F. Corrosion behavior of closed-cell AZ31 Mg alloy foam in $\mathrm{NaCl}$ aqueous solutions. Corros. Sci. 2014, 80, 247-256. [CrossRef]

19. Li, X.; Jiao, F.; Al-Samman, T.; Chowdhury, S.G. Influence of second-phase precipitates on the texture evolution of Mg-Al-Zn alloys during hot deformation. Scr. Mater. 2012, 66, 159-162. [CrossRef]

20. Yang, D.H.; Yang, S.R.; Wang, H.; Ma, A.B.; Jiang, J.H.; Chen, J.Q.; Wang, D.L. Compressive properties of cellular Mg foams fabricated by melt-foaming method. Mater. Sci. Eng. A 2010, 527, 5405-5409. [CrossRef]

21. Xu, Z.G.; Fu, J.W.; Luo, T.J.; Yang, Y.S. Effects of cell size on quasi-static compressive properties of Mg alloy foams. Mater. Des. 2012, 34, 40-44. [CrossRef]

22. Tahreen, N.; Chen, D.L.; Nouri, M.; Li, D.Y. Effects of aluminum content and strain rate on strain hardening behavior of cast magnesium alloys during compression. Mater. Sci. Eng. A 2014, 594, 235-245. [CrossRef]

23. Wilson, D.V. Relationships between microstructure and behavior in the uniaxial tensile test. J. Phys. D Appl. Phys. 1974, 7, 954-968. [CrossRef]

24. Dong, J.G.; Zhang, D.F.; Sun, J.; Dai, Q.W.; Pan, F.S. Effects of different stretching routes on microstructure and mechanical properties of AZ31B magnesium alloy sheets. J. Mater. Sci. Technol. 2015, 31, 935-940. [CrossRef]

25. Pan, H.C.; Wang, F.H.; Li, J.; Feng, M.L.; Dong, J. Mechanical behavior and microstructure evolution of a rolled magnesium alloy AZ31B under low stress triaxiality. J. Mater. Sci. Technol. 2016, 32, 1282-1288. [CrossRef]

26. Lou, S.; Northwood, D.O. Effect of strain aging on the strength coefficient and strain-hardening exponent of construction-grade steels. J. Mater. Eng. Perform. 1994, 3, 344-349. [CrossRef]

27. Hollomon, J.H. Tensile deformation. Trans. AIME 1945, 162, 268-290.

28. Antunes, R.A.; Oliveira, M.C.L.D. Materials selection for hot stamped automotive body parts: An application of the Ashby approach based on the strain hardening exponent and stacking fault energy of materials. Mater. Des. 2014, 63, 247-256. [CrossRef]

29. Wang, C.X.; Jiang, C.H.; Ji, V. Thermal stability of residual stresses and work hardening of shot peened tungsten cemented carbide. J. Mater. Process. Technol. 2017, 240, 98-103. [CrossRef]

30. Juijerm, P.; Altenberger, I. Residual stress relaxation of deep-rolled Al-Mg-Si-Cu alloy during cyclic loading at elevated temperatures. Scr. Mater. 2006, 55, 1111-1114. [CrossRef] 
31. Nikitin, I.; Besel, M. Residual stress relaxation of deep-rolled austenitic steel. Scr. Mater. 2008, 58, $239-242$. [CrossRef]

32. Liu, J.A.; Yu, S.R.; Huang, Z.Q.; Ma, G.; Liu, Y. Microstructure and compressive property of in situ $\mathrm{Mg}_{2} \mathrm{Si}$ reinforced Mg-microballoon composites. J. Alloys Compd. 2012, 537, 12-18. [CrossRef]

33. Rohatgi, P.K.; Daoud, A.; Schultz, B.F.; Puri, T. Microstructure and mechanical behavior of die casting AZ91D-Fly ash cenosphere composites. Compos. Part A Appl. Sci. Manuf. 2009, 40, 883-896. [CrossRef]

34. Xu, C.; Sheng, G.G.; Wang, H.; Feng, K.; Yuan, X.J. Tungsten inert gas welding-brazing of AZ31B magnesium alloy to TC4 titanium alloy. J. Mater. Sci. Technol. 2016, 32, 167-171. [CrossRef]

35. Gupta, N.; Luong, D.D.; Rohatgi, P.K. A method for intermediate strain rate compression testing and study of compressive failure mechanism of Mg-Al-Zn alloy. J. Appl. Phys. 2011, 109, 103512. [CrossRef]

36. Lü, Y.Z.; Wang, Q.D.; Ding, W.J.; Zeng, X.Q.; Zhu, Y.P. Fracture behavior of AZ91 magnesium alloy. Mater. Lett. 2000, 44, 265-268. [CrossRef]

37. Li, B.; Pan, Q.L.; Shi, Y.J.; Chen, L.I.; Yin, Z.M. Microstructural evolution of Al-Zn-Mg-Zr alloy with trace amount of Sc during homogenization treatment. Trans. Nonferr. Met. Soc. China 2013, 23, 3568-3574. [CrossRef]

(C) 2018 by the authors. Licensee MDPI, Basel, Switzerland. This article is an open access article distributed under the terms and conditions of the Creative Commons Attribution (CC BY) license (http:/ / creativecommons.org/licenses/by/4.0/). 